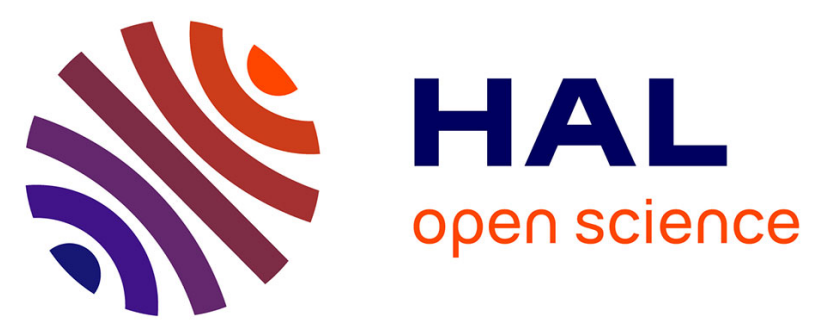

\title{
Geochemical constraints on carboniferous volcanic rocks of Yili Block (Xinjiang, NW China); implication for the tectonic evolution of western Tianshan.
}

Bo Wang, Liangshu S. Shu, Dominique Cluzel, Michel Faure, Jacques Charvet

\section{- To cite this version:}

Bo Wang, Liangshu S. Shu, Dominique Cluzel, Michel Faure, Jacques Charvet. Geochemical constraints on carboniferous volcanic rocks of Yili Block (Xinjiang, NW China); implication for the tectonic evolution of western Tianshan.. Journal of Southeast Asian earth sciences, 2007, 29, pp.148-159. 10.1016/j.jseaes.2006.02.008 . hal-00091027

\section{HAL Id: hal-00091027 \\ https://hal-insu.archives-ouvertes.fr/hal-00091027}

Submitted on 28 Feb 2007

HAL is a multi-disciplinary open access archive for the deposit and dissemination of scientific research documents, whether they are published or not. The documents may come from teaching and research institutions in France or abroad, or from public or private research centers.
L'archive ouverte pluridisciplinaire HAL, est destinée au dépôt et à la diffusion de documents scientifiques de niveau recherche, publiés ou non, émanant des établissements d'enseignement et de recherche français ou étrangers, des laboratoires publics ou privés. 


\title{
Geochemical constraints on Carboniferous volcanic rocks of the Yili Block (Xinjiang, NW China): Implication for the tectonic evolution of Western Tianshan
}

\author{
B. Wang ${ }^{\mathrm{a}}$ b, L.S. Shu ${ }^{\mathrm{a}}$, D. Cluzel ${ }^{\mathrm{b}}$, M. Faure ${ }^{\mathrm{b}}$ and J. Charvet $^{\mathrm{b}}$ \\ ${ }^{a}$ Department of Earth Sciences, Nanjing University, Nanjing 210093, China \\ ${ }^{\mathrm{b}}$ ISTO UMR 6113, University of Orléans, F45067 Orléans, Cedex 2, France
}

\section{Abstract}

The Yili Block is important for understanding the Late Paleozoic geodynamic evolution of Central Asia. It is bounded to the north by the Northern Tianshan Carboniferous flysch and ophiolitic mélange. The center of the Block is dominated by Carboniferous sedimentary rocks with intercalation of volcanic rocks. Petrological and geochemical features of these Carboniferous volcanic rocks show that: (1) they belong to the calc-alkaline series, (2) they display prominent $\mathrm{Nb}-\mathrm{Ta}$ negative anomalies consistent with subduction-related magmas, and (3) HFSE-based discriminations place these volcanic rocks in the field of continental arcs. The depositional evolution of the sedimentary series shows evidence for Carboniferous sedimentation in a basin instead of rifting as previously proposed. All these evidences, together with the occurrence of contemporaneous turbidites and ophiolitic mélange along the northern boundary of the Yili Block, allow us to infer that the northern border of the Yili Block was a continental active margin during the Carboniferous. The Late Carboniferous southward subduction that finally closed the Late Devonian to Early Carboniferous North Tianshan oceanic basin was followed by Permian-Mesozoic polyphase transcurrent faulting.

Keywords: Geochemistry; Volcanic rocks; Continental arc; Carboniferous; Yili Block; Chinese Tianshan Belt

\section{Introduction}

The "Yili Block" represents the easternmost part of a large continental block, which mainly occurs in Kazakhstan where it is known as the "Ili" block (Sengör and Natal'in, 1996). This large continental unit is bounded by suture zones and large scale strike-slip faults (Fig. 1). It is composed of several tectonic units and their history of amalgamation remains controversial. A first model suggests a progressive growth of the Asian continent in the Paleozoic by colliding fragments in a continuously converging setting (Natal'in and Sengör, 1994, Sengör et al., 1993, Shi et al., 1994 and Shu et al., 2000). Alternatively, it has been suggested that the Tarim plate formed during the Late Proterozoic, and thereafter, the Yili Block was rifted from Tarim during the Ordovician. The final suturing event occurred between the Tarim, the Junggar, and the Kazakhstan blocks during the Late Paleozoic (Chen et al., 1999, Gao et al., 1995, Gao et al., 1997, Gao et al., 1998, Ma et al., 1993 and Xiao et al., 1992). The final stages of suturing are still poorly understood as well. Models of continuous convergence (Gao et al., 1998 and Xiao et al., 1992), or alternatively, marginal rifting and subsequent re-amalgamation (Che et al., 1996 and Xia et al., 2003) have been proposed. In this paper, we intend to clarify the Carboniferous evolution of the northern part of the Yili Block by studying the Carboniferous volcanic rocks. 


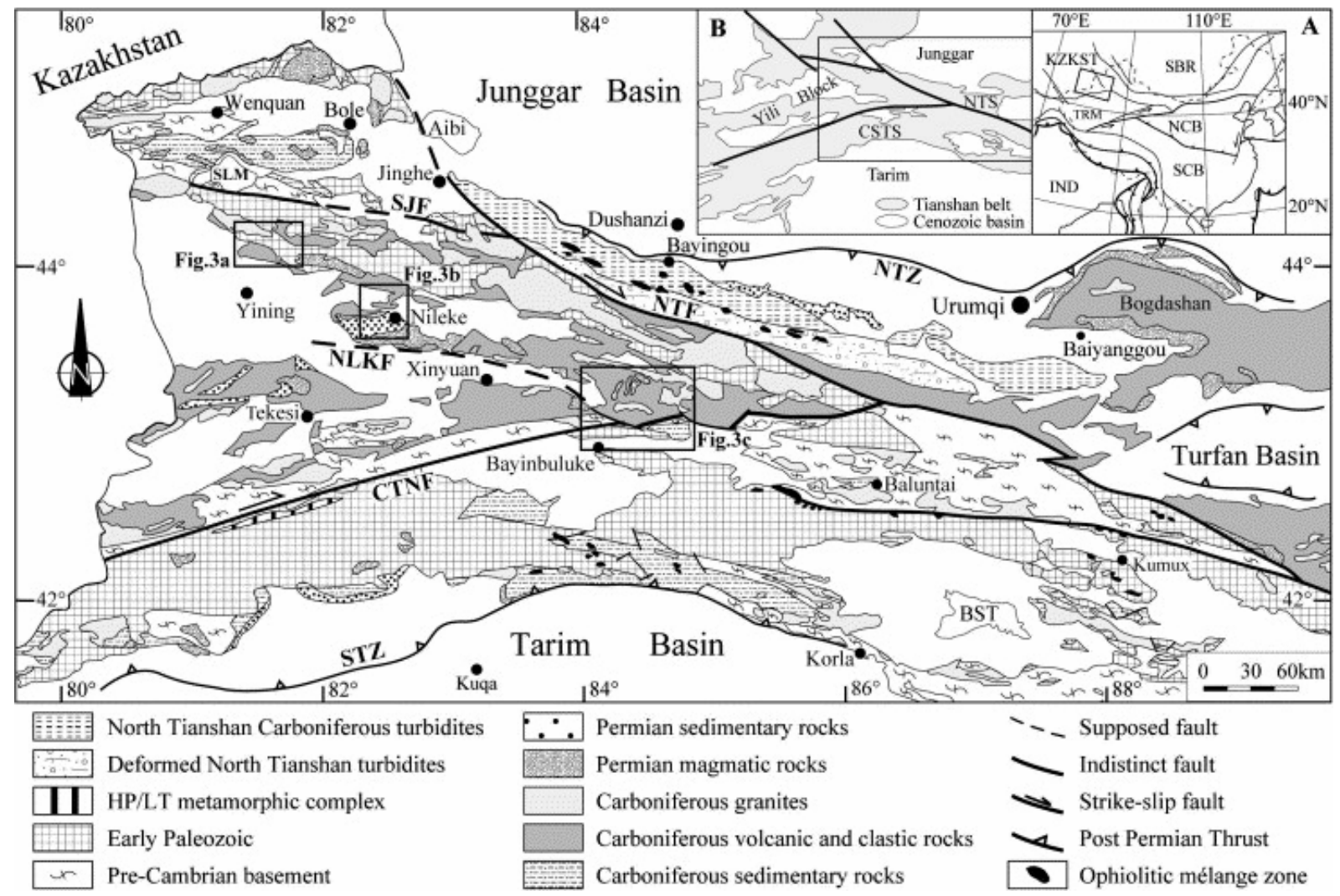

Fig. 1. Simplified geological map of the Western Tianshan Belt showing the localities of the main tectonic boundaries (modified from XBGMR, 1992). Inset A shows the location of inset B, which defines the Yili Block, the North Tianshan (NTS), the Central-South Tianshan (CSTS), Junggar and Tarim. Abbreviations: NTZ, the Northern Thrust Zone; STZ, the Southern Thrust Zone; NTF, the Northern Tianshan Fault; CTNF, the Central Tianshan Northern Margin Fault; SJF, the Sailimu (SLM)-Jinghe Fault; NLKF, the Nileke Fault; SLM, Sailimu Lake; BST, Bosteng Lake. KZKST, Kazakhstan; SBR, Siberia; TRM, Tarim; NCB, North China Block; SCB, South China Block; IND, India.

In Western China, the Yili Block geographically lies west of the Xinjiang Uygur Autonomous Region and is geologically one of the main parts of the Chinese Tianshan Belt. It separates the Northern Tianshan (NTS) to the north and the Central-Southern Tianshan (CSTS) to the south, respectively (inset B of Fig. 1). The Yili Block is in contact with the NTS along the North Tianshan Fault (NTF in Fig. 1; Zhou et al., 2001) and with the CSTS along the Central Tianshan Northern Margin Fault (Xiao et al., 1992; CTNF in Fig. 1). The Sailimu (SLM)Jinghe Fault (SJF in Fig. 1) separates the Yili Block to the south from the "Bole Block" to the north. These boundaries were also defined and discussed by Sengör and Natal'in (1996). Late Paleozoic volcanic and volcano-sedimentary rocks are widely developed in the northern, southern and eastern margins of the Yili Block, while Mesozoic and Cenozoic terrestrial sedimentary rocks cover the interior of the Yili Block, which is called the Yili Basin. The volcanic and volcano-sedimentary rocks were dated as Carboniferous by paleontologic and radiochronologic methods (Li et al., 1998 and XBGMR, 1993). Since the 1990's, the tectonic setting of Carboniferous volcanism in the Yili Block has been a matter of debate. It has been interpreted either as an active margin (Gao et al., 1997, Gao et al., 1998, Jiang et al., 1995 and Xiao et al., 1992) or as a continental rift (Che et al., 1996, Chen et al., 2001, Xia et al., 2002 and Xia et al., 2003). Until now, only a few detailed geochemical data were available and thus the tectonic setting of these rocks was poorly constrained. In this paper, we describe the geochemical features of Yili Carboniferous volcanic rocks, and discuss their tectonic setting in relation to the published data. Geochemical evidence, combined with the occurrence of a 
Late Carboniferous ophiolitic mélange that crops out to the north of the Yili Block, allows us to propose a simplified model of the geological evolution and final amalgamation of Central Asia during the Late Paleozoic.

\section{Geological background}

The Yili Block is a triangular area that extends more than $1000 \mathrm{~km}$ across the borderlines of China, Kazakhstan and Kyrgyzstan, and its geodynamic evolution since the Late Paleozoic is closely related to the Tianshan Belt (Fig. 1). The eastern part of the Yili Block is one of the main parts of the Western Chinese Tianshan (WTS) Belt, which is bounded by two major active thrusts, the southern thrust zone (STZ) and the northern thrust zone (NTZ) that separate the WTS Belt from the Tarim Basin and the Junggar Basin (Fig. 1), respectively. The Chinese Tianshan Belt is generally divided into three units: the Northern, the Central and the Southern Tianshan belts, which are separated from one other by regional-scale strike-slip faults (Allen et al., 1993, Allen et al., 1999, Coleman, 1989, Ma et al., 1993 and Windley et al., 1990). The geological evolution of the Tianshan Belt has been discussed during the last two decades. Generally, it is considered a result of multiphase amalgamation and accretion of various micro-continents that include the Yili Block, magmatic arcs and terranes throughout the Paleozoic (Coleman, 1989, Shi et al., 1994, Shu et al., 2000 and Shu et al., 2002). It was deformed again by Cenozoic intra-continental tectonics and subsequently uplifted in response to the India-Asia collision (Avouac et al., 1993, Burchfiel et al., 1999, Cunningham et al., 1996, Shu et al., 2003 and Tapponnier and Molnar, 1979).

The Proterozoic basement of the Yili Block crops out along its boundaries (Fig. 1). The Mesoto Neoproterozoic carbonates and clastic rocks of the Jixian and Qingbaikou formations are developed in the Sailimu Lake (SLM)-Wenquan area and southeast of Tekesi. The Sinian red sandstone and minor "tillite" (Gao et al., 1998, XBGMR, 1993 and Xia et al., 2002) are exposed to the south of SLM. Precambrian amphibolite facies metamorphic rocks mainly crop out in the Bingdaban-Baluntai area, south of Urumqi. They were also recognized at Nalati Pass, north of Bayinbuluke, and in the Haerke Mountains, south of Tekesi (Fig. 1), and respectively dated by $\mathrm{U}-\mathrm{Pb}$ method on zircon at $882 \pm 33 \mathrm{Ma}$ (Chen et al., 2000a) and $709 \pm 13 \mathrm{Ma}$ (Chen et al., 2000b). Lower and Middle Paleozoic strata are mainly developed along the northern margin of the Yili Block. Cambrian and Ordovician rocks consist of chert, and carbonates and predominantly crop out in the Sailimu Lake and Guozigou area (Fig. 1). Silurian flysch and intercalated calc-alkaline volcanic and volcano-sedimentary rocks are distributed along the southern side of NTF and along the eastern margin of the Yili Block (XBGMR, 1993 and Zhou et al., 2001). The Devonian is only represented by granitoids in the Yili Block.

Carboniferous rocks are widespread in the study area and are divided into two parts ranging from Early Carboniferous (C1) to Late Carboniferous (C2). Each part consists of several formations as shown in Fig. 2 that correlate with the international stratigraphic chart (ICS, 2004). The lower part (C1), ca. $3500 \mathrm{~m}$ thick, is predominantly composed of limestone, sandstone and shale with subordinate volcanic rocks. The upper part (C2), which unconformably overlies $\mathrm{C} 1$, consists of limestone intercalated with volcaniclastic sandstone and massive volcanic rocks (Fig. 2). The basement and pre-Carboniferous rocks are croscut by voluminous granitoids of Carboniferous age (XBGMR, 1993; Fig. 1 and Fig. 2). This lithotectonic unit is quite different from that of the North Tianshan Belt, where Carboniferous rocks consist of turbidite flysch and ophiolitic mélange (Fig. 2). Due to possible tectonic duplication, the thickness of the North Tianshan flysch is difficult to establish. However it is 
estimated to be between 5000 and 10,000 m thick. On paleontological grounds (ammonoids and plant fossils), the flysch has been correlated to the upper half of $\mathrm{C} 1$ to $\mathrm{C} 2$ (XBGMR, 1993; Fig. 2). The mélange zone contains metre- to kilometer-scale blocks of Late Devonian to Early Carboniferous oceanic lithosphere such as radiolarian-bearing cherts (Xiao et al., 1992) along with reworked Carboniferous flysch boulders (Fig. 2), and therefore formed during Late the $\mathrm{C} 2$ interval.

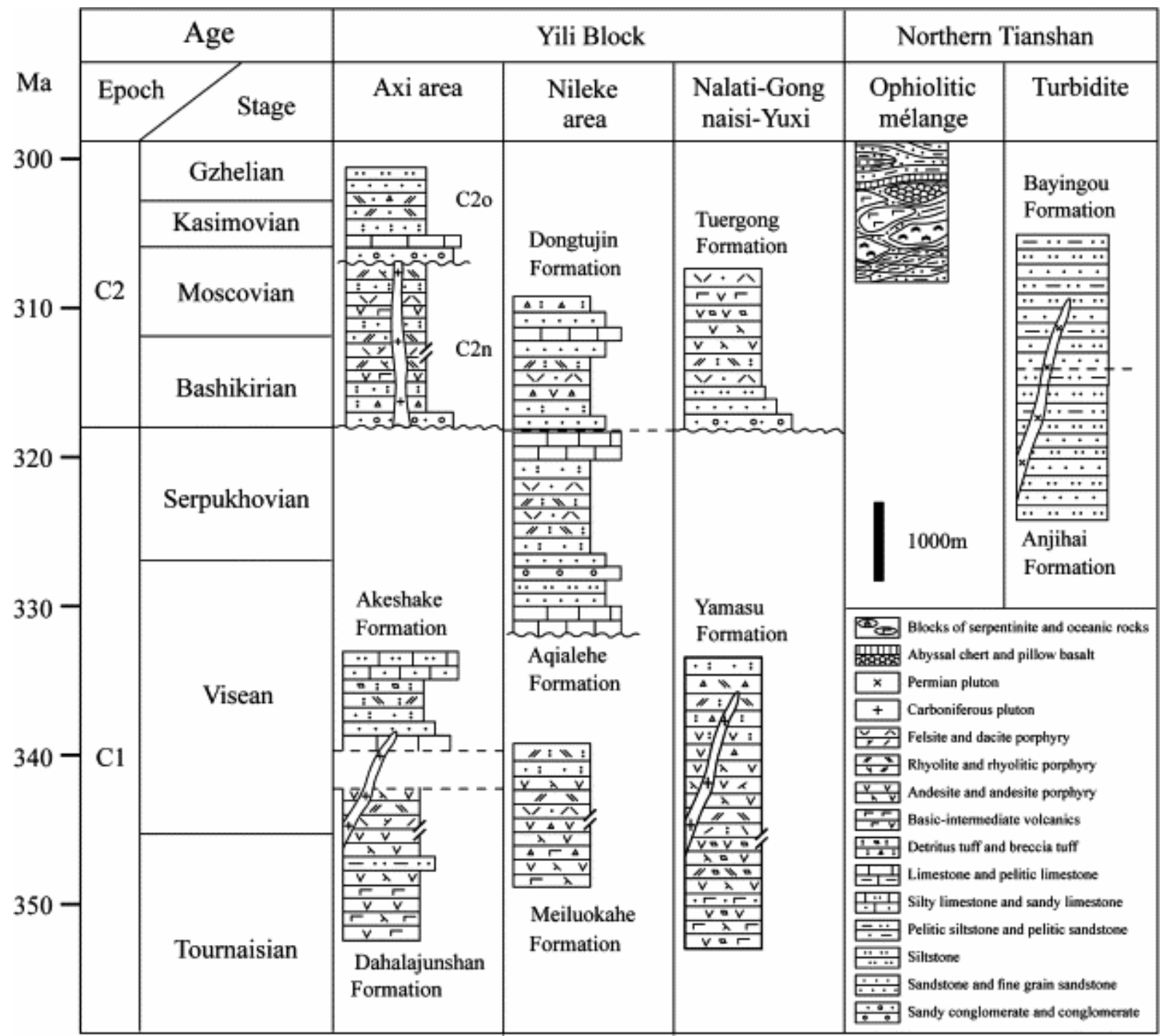

Fig. 2. Schematic Carboniferous chronostratigraphic columns of the Yili Block and the Northern Tianshan Belt compared to the international stratigraphic chart (ICS, 2004). Time scale and stratigraphy modified from XBGMR, 1992 and XBGMR, 1993. C2o, the Oyiman Formation; C2n, the Naogaitu Formation.

Permian terrestrial sandstone and conglomerate unconformably overlie all the older rocks. A prominent bimodal volcanic association developed in the Nileke area (Fig. 1 and Fig. 3b; Wang et al., 1997, XBGMR, 1992 and XBGMR, 1993). Felsic and/or mafic magmatism is also recognized and discussed for the Baiyanggou area of Bogdashan (Allen et al., 1995 and Shu et al., 2005). Permian plutonic rocks are also widespread in the study area. Lateral shear zones deformed the boundaries of the Yili Block during the Late Carboniferous-Early Permian and underwent polyphase reactivation during the early Mesozoic (Bazhenov et al., 1999, Laurent-Charvet et al., 2002, Laurent-Charvet et al., 2003, Shu et al., 1999 and Shu et al., 2003). 


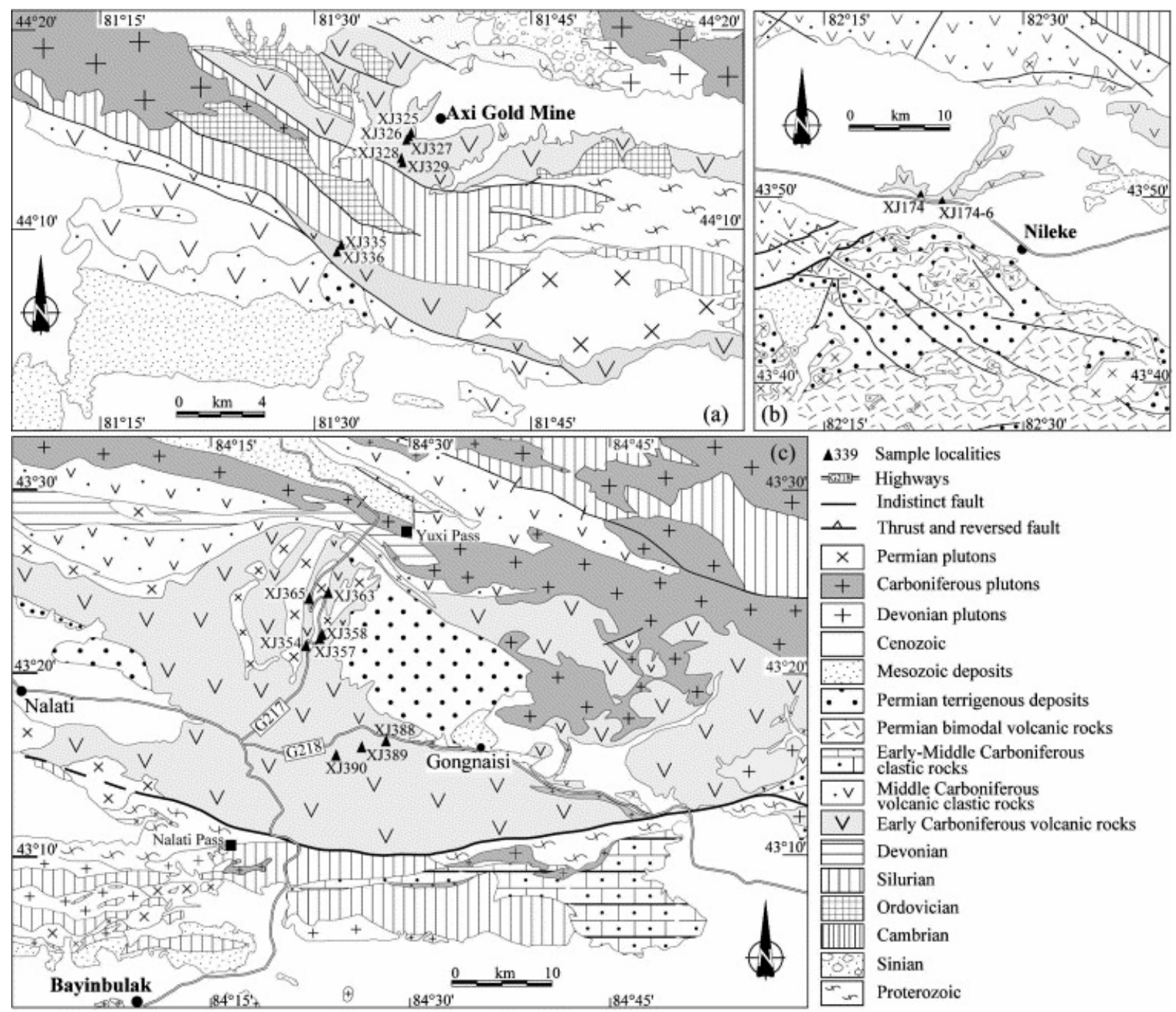

Fig. 3. Geological maps of (a) the Axi section, (b) the Northern Nileke section and (c) the Nalati-GongnaisiYuxi section.

\section{Representative geological sections of Carboniferous volcanic rocks}

About 200 samples of Carboniferous volcanic rocks were collected for this study from the Axi section of the northern Yining, the northern Nileke section and the Nalati-GongnaisiYuxi section as shown in Fig. 1. Samples are listed in Table 1 and the sample locations are shown in Fig. 3. The rocks mainly belong to the basic-intermediate volcanic series, but also include a few acidic volcanic rocks, tuff, and greywackes.

Table 1. : ICP-MS whole rock analyzed results of representative samples from the Yili Block 


\begin{tabular}{|c|c|c|c|c|c|c|c|c|c|c|c|c|c|c|c|c|c|c|c|}
\hline \multirow[t]{2}{*}{ Samples } & \multicolumn{8}{|c|}{ The Axi section } & \multicolumn{3}{|c|}{ The Northern Nileke section } & \multicolumn{8}{|c|}{ The Nalati-Gongnaisi-Yuxi section } \\
\hline & XJ-325 & $\mathrm{XJ}-326$ & $\mathrm{XJ}-327$ & $\mathrm{XJ}-328$ & XJ-329 & XJ-335 & XJ-335-1 & XJ-336 & XJ-174 & XJ-174-1 & XJ-174-6 & XJ-363 & $\mathrm{XJ}-365$ & XJ-388 & XJ-389 & XJ-390 & $\mathrm{XJ}-354$ & XJ-357 & $\mathrm{XJ}-358$ \\
\hline $\mathrm{SiO}_{2}(\mathrm{wt} \%)$ & 53.42 & 54.04 & 53.18 & 55.19 & 59.21 & 68.81 & 67.42 & 68.83 & 49.70 & 50.61 & 66.54 & 57.43 & 68.71 & 46.63 & 46.56 & 50.05 & 56.15 & 55.93 & 36.55 \\
\hline $\mathrm{TiO}_{2}$ & 0.84 & 0.85 & 0.94 & 1.21 & 0.90 & 0.44 & 0.38 & 0.43 & 0.99 & 0.93 & 0.71 & 0.98 & 0.89 & 0.94 & 0.90 & 1.11 & 0.85 & 2.22 & 1.80 \\
\hline $\mathrm{Al}_{2} \mathrm{O}_{3}$ & 16.54 & 16.78 & 17.20 & 16.55 & 16.32 & 15.71 & 14.15 & 15.62 & 19.60 & 19.02 & 15.86 & 17.51 & 13.00 & 18.44 & 17.28 & 18.60 & 17.63 & 13.86 & 26.61 \\
\hline $\mathrm{Fe}_{2} \mathrm{O}_{3}$ & 8.21 & 7.21 & 7.94 & 7.52 & 5.58 & 3.12 & 1.91 & 2.52 & 10.26 & 9.74 & 4.30 & 7.33 & 4.18 & 8.32 & 8.96 & 9.65 & 8.49 & 10.48 & 24.62 \\
\hline $\mathrm{MnO}$ & 0.12 & 0.13 & 0.13 & 0.12 & 0.10 & 0.13 & 0.19 & 0.11 & 0.40 & 0.22 & 0.14 & 0.19 & 0.13 & 0.70 & 1.18 & 0.30 & 0.20 & 0.36 & 0.15 \\
\hline $\mathrm{MgO}$ & 3.13 & 3.40 & 5.98 & 4.43 & 3.30 & 0.36 & 0.41 & 0.36 & 4.33 & 3.94 & 1.29 & 1.56 & 0.69 & 3.57 & 2.67 & 2.94 & 1.95 & 2.82 & 0.02 \\
\hline $\mathrm{CaO}$ & 6.83 & 7.99 & 3.32 & 6.97 & 3.51 & 1.46 & 5.06 & 1.75 & 4.92 & 7.19 & 1.16 & 2.63 & 1.12 & 8.83 & 6.55 & 4.52 & 1.81 & 3.97 & 0.26 \\
\hline $\mathrm{Na}_{2} \mathrm{O}$ & 3.05 & 2.80 & 5.21 & 3.21 & 3.32 & 3.88 & 1.55 & 4.24 & 4.80 & 4.12 & 5.36 & 3.68 & 2.82 & 2.81 & 2.66 & 6.13 & 3.11 & 4.43 & 0.10 \\
\hline $\mathrm{K}_{2} \mathrm{O}$ & 0.60 & 0.52 & 0.22 & 2.24 & 2.97 & 4.12 & 3.49 & 3.16 & 0.99 & 1.22 & 4.01 & 6.53 & 6.58 & 3.77 & 6.27 & 1.59 & 7.05 & 3.40 & 0.22 \\
\hline $\mathrm{P}_{2} \mathrm{O}_{5}$ & 0.16 & 0.16 & 0.18 & 0.25 & 0.18 & 0.12 & 0.11 & 0.10 & 0.25 & 0.24 & 0.16 & 0.60 & 0.19 & 0.28 & 0.23 & 0.22 & 0.54 & 0.92 & 0.58 \\
\hline LOI & 8.39 & 7.79 & 5.96 & 2.23 & 4.42 & 2.09 & 5.98 & 2.51 & 4.52 & 2.72 & 1.21 & 1.45 & 0.89 & 5.88 & 6.45 & 5.36 & 1.73 & 1.41 & 9.44 \\
\hline Total & 101.29 & 101.67 & 100.26 & 99.91 & 99.79 & 100.23 & 100.64 & 99.63 & 100.75 & 99.95 & 100.72 & 99.88 & 99.20 & 100.18 & 99.69 & 100.46 & 99.50 & 99.80 & 100.36 \\
\hline $\mathrm{Sc}(\mathrm{ppm})$ & 23.49 & 24.05 & 27.27 & 22.58 & 16.74 & 3.552 & 2.978 & 3.022 & 31.2 & 30.46 & 12.84 & 13.86 & 26.52 & 24.7 & 16.64 & 11.25 & 27.81 & 28.36 & 22.29 \\
\hline $\mathrm{Ti}$ & 4746.1 & 5096.7 & 5484.9 & 8417 & 5237.1 & 2756.1 & 2351.7 & 2557.1 & 5655.1 & 5459.4 & 4134.3 & 4924.2 & 15014 & 10797 & 5405.7 & 4987.2 & 5444.6 & 4921.4 & 5844.7 \\
\hline V & 130.4 & 180.3 & 229.6 & 197.3 & 129.8 & 18.59 & 21.31 & 15.8 & 253.5 & 243.2 & 45.46 & 102.4 & 169.6 & 572.9 & 105.4 & 12.17 & 278.6 & 241.8 & 231.4 \\
\hline $\mathrm{Cr}$ & 62 & 65.07 & 95.27 & 62.18 & 74.07 & 3.014 & 2.759 & 5.727 & 33.8 & 30.53 & 5.416 & 10.58 & 2.697 & 50.92 & 5.476 & 10.77 & 85.73 & 16.89 & 10.82 \\
\hline $\mathrm{Mn}$ & 866.8 & 937.8 & 975.8 & 920.9 & 738 & 939.9 & 1410.8 & 801.3 & 2865.6 & 1704.8 & 989.7 & 1502.7 & 2534 & 1029.5 & 1366.7 & 870.5 & 5174.8 & 6698.6 & 2034.2 \\
\hline Co & 18.69 & 20.47 & 26.23 & 21.56 & 16.95 & 4.174 & 2.22 & 3.538 & 28.47 & 26.94 & 5.944 & 12.66 & 17.33 & 13.02 & 23.52 & 2.124 & 28.56 & 14.45 & 32.86 \\
\hline $\mathrm{Ni}$ & 21.45 & 22.84 & 33.06 & 41.01 & 32.13 & 2.519 & 4.616 & 4.754 & 18.44 & 18.97 & 3.471 & 7.678 & 2.95 & 16.96 & 13.73 & 6.644 & 59.24 & 11.36 & 21.67 \\
\hline $\mathrm{Cu}$ & 20.78 & 71.54 & 174.2 & 60.34 & 70.41 & 5.416 & 16.06 & 5.83 & 22.58 & 84.56 & 11.31 & 156.8 & 9.101 & 22.39 & 295.8 & 5.357 & 21.95 & 50 & 34.76 \\
\hline
\end{tabular}




\begin{tabular}{|c|c|c|c|c|c|c|c|c|c|c|c|c|c|c|c|c|c|c|c|}
\hline \multirow[t]{2}{*}{ Samples } & \multicolumn{8}{|c|}{ The Axi section } & \multicolumn{3}{|c|}{ The Northern Nileke section } & \multicolumn{8}{|c|}{ The Nalati-Gongnaisi-Yuxi section } \\
\hline & XJ-325 & $\mathrm{XJ}-326$ & XJ-327 & XJ-328 & XJ-329 & XJ-335 & XJ-335-1 & $\mathrm{XJ}-336$ & XJ-174 & XJ-174-1 & XJ-174-6 & XJ-363 & XJ-365 & XJ-388 & XJ-389 & XJ-390 & XJ-354 & XJ-357 & XJ-358 \\
\hline $\mathrm{Zn}$ & 64.45 & 56.89 & 69.08 & 71.22 & 57.55 & 70.74 & 74.71 & 110 & 254.5 & 90.27 & 153.6 & 135.4 & 172.6 & 46.38 & 101.7 & 147.6 & 667.1 & 398 & 158.7 \\
\hline $\mathrm{Ga}$ & 17.07 & 18.26 & 23 & 19.09 & 19.01 & 18.83 & 17.4 & 18.75 & 17.36 & 18.36 & 15.63 & 17.72 & 18.46 & 32.86 & 17.75 & 13.75 & 18.68 & 16 & 17.71 \\
\hline $\mathrm{Ge}$ & 0.879 & 0.957 & 1.271 & 1.245 & 0.966 & 1.09 & 1.471 & 1.258 & 0.983 & 1.25 & 1.155 & 1.434 & 1.677 & 2.2 & 1.174 & 1.251 & 1.311 & 1.394 & 0.855 \\
\hline $\mathrm{Rb}$ & 24.08 & 22.9 & 5.84 & 86.8 & 126 & 142.2 & 141.2 & 111.4 & 21.87 & 27.52 & 118.2 & 262.6 & 162.9 & 9.573 & 252.5 & 196.3 & 144.7 & 295.4 & 84.55 \\
\hline $\mathrm{Sr}$ & 194.8 & 201.9 & 124.4 & 463.3 & 194.2 & 145.5 & 86.66 & 128.5 & 457.2 & 613.1 & 105.4 & 221.6 & 338.4 & 4382 & 344.2 & 19.96 & 486.8 & 509.3 & 306.7 \\
\hline Y & 19.29 & 21.09 & 23.3 & 30.77 & 26.19 & 26.9 & 25.31 & 29.24 & 18.78 & 19.55 & 34.7 & 28.36 & 54.52 & 22.94 & 30.9 & 59.77 & 22.13 & 19.8 & 27.84 \\
\hline $\mathrm{Zr}$ & 124.7 & 134.5 & 165.2 & 220.2 & 209 & 208.8 & 189.8 & 210.8 & 62.81 & 78.11 & 261.8 & 222.2 & 237.5 & 212.2 & 198.4 & 352.8 & 79.16 & 61.46 & 113.4 \\
\hline $\mathrm{Nb}$ & 5.976 & 6.396 & 8.115 & 10.35 & 11.11 & 34.39 & 31.53 & 32.51 & 3.158 & 3.16 & 13.33 & 10.3 & 9.415 & 9.828 & 10.97 & 13.49 & 3.524 & 2.445 & 4.302 \\
\hline $\mathrm{Ba}$ & 575.6 & 180.4 & 26.37 & 353.8 & 538.4 & 638.4 & 99.68 & 441.5 & 197 & 339.7 & 933.2 & 928.3 & 772.3 & 141.7 & 682.5 & 183.4 & 883.5 & 2234.9 & 108.2 \\
\hline $\mathrm{La}$ & 14.73 & 15.17 & 18.67 & 23.11 & 27.55 & 49.49 & 41.37 & 50.25 & 10.23 & 10.18 & 36.72 & 29.06 & 26.29 & 38.68 & 37.54 & 25.54 & 19.29 & 12.6 & 10.73 \\
\hline $\mathrm{Ce}$ & 32.35 & 34.03 & 41.36 & 50.95 & 58.06 & 93.61 & 81.05 & 95.04 & 22.99 & 22.28 & 73.64 & 68.6 & 62.48 & 164.6 & 79.44 & 62.73 & 37.59 & 26.94 & 25.06 \\
\hline $\operatorname{Pr}$ & 3.938 & 4.202 & 5.078 & 6.22 & 6.757 & 10.19 & 8.941 & 10.63 & 3.109 & 2.979 & 8.309 & 8.586 & 8.559 & 39.01 & 10.51 & 8.941 & 4.793 & 3.529 & 3.541 \\
\hline $\mathrm{Nd}$ & 15.99 & 17.42 & 20.14 & 25.38 & 26.29 & 35.51 & 31.35 & 36.66 & 13.96 & 13.48 & 32.66 & 34.45 & 39.06 & 213.2 & 42.66 & 39.34 & 20.68 & 16.06 & 15.63 \\
\hline $\mathrm{Sm}$ & 3.7 & 3.878 & 4.389 & 5.507 & 5.571 & 6.021 & 5.839 & 6.225 & 3.237 & 3.257 & 6.592 & 7.41 & 9.726 & 36.19 & 8.467 & 9.875 & 4.86 & 3.835 & 4.046 \\
\hline $\mathrm{Eu}$ & 0.99 & 1.053 & 1.232 & 1.307 & 1.169 & 1.181 & 1.422 & 1.164 & 1.189 & 1.13 & 1.52 & 1.462 & 2.719 & 5.207 & 1.72 & 2.317 & 1.297 & 0.953 & 1.335 \\
\hline $\mathrm{Gd}$ & 3.874 & 3.998 & 4.641 & 5.682 & 5.267 & 4.922 & 5.164 & 5.132 & 3.757 & 3.653 & 6.897 & 6.581 & 11.17 & 7.621 & 7.151 & 11.03 & 4.89 & 4.202 & 4.921 \\
\hline $\mathrm{Tb}$ & 0.62 & 0.642 & 0.707 & 0.904 & 0.839 & 0.807 & 0.817 & 0.834 & 0.573 & 0.559 & 1.051 & 0.961 & 1.664 & 0.782 & 1.025 & 1.729 & 0.72 & 0.614 & 0.776 \\
\hline Dy & 3.551 & 3.769 & 4.176 & 5.268 & 4.875 & 4.623 & 4.31 & 4.694 & 3.441 & 3.346 & 6.177 & 5.204 & 9.904 & 3.867 & 5.476 & 10.37 & 4.113 & 3.555 & 4.787 \\
\hline Ho & 0.709 & 0.746 & 0.858 & 1.06 & 0.988 & 0.916 & 0.816 & 0.952 & 0.695 & 0.674 & 1.27 & 1.025 & 1.974 & 0.842 & 1.091 & 2.115 & 0.815 & 0.728 & 0.995 \\
\hline $\mathrm{Er}$ & 2.04 & 2.086 & 2.339 & 2.922 & 2.685 & 2.609 & 2.336 & 2.685 & 1.904 & 1.863 & 3.62 & 2.843 & 5.419 & 2.631 & 3.073 & 6.183 & 2.175 & 2.013 & 2.801 \\
\hline
\end{tabular}




\begin{tabular}{|c|c|c|c|c|c|c|c|c|c|c|c|c|c|c|c|c|c|c|c|}
\hline \multirow[t]{2}{*}{ Samples } & \multicolumn{8}{|c|}{ The Axi section } & \multicolumn{3}{|c|}{ The Northern Nileke section } & \multicolumn{8}{|c|}{ The Nalati-Gongnaisi-Yuxi section } \\
\hline & XJ-325 & XJ-326 & XJ-327 & $\mathrm{XJ}-328$ & XJ-329 & XJ-335 & XJ-335-1 & XJ-336 & XJ-174 & XJ-174-1 & XJ-174-6 & $\mathrm{XJ}-363$ & XJ-365 & XJ-388 & XJ-389 & XJ-390 & XJ-354 & XJ-357 & XJ-358 \\
\hline $\mathrm{Tm}$ & 0.316 & 0.322 & 0.364 & 0.437 & 0.417 & 0.4 & 0.353 & 0.426 & 0.277 & 0.294 & 0.573 & 0.447 & 0.802 & 0.458 & 0.454 & 0.946 & 0.336 & 0.303 & 0.447 \\
\hline $\mathrm{Yb}$ & 2.108 & 2.212 & 2.403 & 2.951 & 2.639 & 2.813 & 2.393 & 2.941 & 1.869 & 1.9 & 3.879 & 2.892 & 5.309 & 3.422 & 3.07 & 6.316 & 2.22 & 2 & 2.898 \\
\hline $\mathrm{Lu}$ & 0.335 & 0.366 & 0.394 & 0.481 & 0.426 & 0.475 & 0.388 & 0.493 & 0.308 & 0.311 & 0.663 & 0.486 & 0.857 & 0.569 & 0.498 & 1.035 & 0.362 & 0.325 & 0.477 \\
\hline $\mathrm{Hf}$ & 3.437 & 3.521 & 4.16 & 5.405 & 5.744 & 5.825 & 5.012 & 5.577 & 1.673 & 1.951 & 7.012 & 4.807 & 5.962 & 4.996 & 4.989 & 9.168 & 2.066 & 1.692 & 2.804 \\
\hline $\mathrm{Ta}$ & 0.437 & 0.446 & 0.567 & 0.701 & 0.874 & 2.34 & 2.087 & 2.193 & 0.183 & 0.194 & 0.866 & 0.666 & 0.611 & 0.558 & 0.686 & 0.845 & 0.204 & 0.146 & 0.261 \\
\hline Th & 4.016 & 4.128 & 5.895 & 7.989 & 10.87 & 23.85 & 20.69 & 22.23 & 1.272 & 1.217 & 11.12 & 16.07 & 6.425 & 10.78 & 17.55 & 10.06 & 4.351 & 2.883 & 1.97 \\
\hline $\mathrm{U}$ & 1.043 & 1.139 & 1.558 & 1.994 & 3.119 & 4.147 & 4.922 & 4.513 & 0.39 & 0.337 & 2.846 & 2.996 & 1.979 & 3.061 & 4.297 & 2.811 & 1.124 & 1.059 & 0.551 \\
\hline
\end{tabular}




\subsection{The Axi section}

This section is located $30 \mathrm{~km}$ to the north of Yining City. It is composed of sandstone and basic to intermediate volcanic rocks (Fig. 3a). In the northern part of the section, the Early Carboniferous volcanic rocks are correlated to the Dahalajunshan Formation (C1d) (XBGMR, 1993). Pyroxene-bearing andesites yield a $\mathrm{Rb}-\mathrm{Sr}$ whole rock-mineral isochron age of $345.9 \pm 9 \mathrm{Ma}$ and $\mathrm{a}{ }^{40} \mathrm{Ar}-{ }^{39} \mathrm{Ar}$ plateau age of $325.1 \pm 0.6 \mathrm{Ma}$ ( $\mathrm{Li}$ et al., 1998). The Dahalajunshan Formation is mainly composed of basalt, andesite and minor rhyolite and dacite. The Dahalajunshan Formation is overlain unconformably by the Akeshake Formation (C1ak), which is mainly composed of sandstone and limestone (XBGMR, 1993). To the south, the intermediate to acidic volcanic and volcano-sedimentary rocks in the lower part of the Late Carboniferous Naogaitu Formation $(\mathrm{C} 2 \mathrm{n})$ are overlain by limestone, mudstone, siltstone and sandstone of the Oyiman Formation (C2o) (Fig. 2).

\subsection{The northern Nileke section}

Along the highway to the northwest of Nileke County (Fig. 3b), the Aqialehe Formation (C1a) (Fig. 2; XBGMR, 1993) consist of intermediate to acidic volcaniclastic rocks. Although no age was documented for these volcanic rocks, they are correlated with the Early Carboniferous rocks that laterally crop out in the Borohoro Mountains, south of NTF (XBGMR, 1993; Fig. 1). In this area, Early Carboniferous rocks consist of sandstone, conglomerate and limestone in the lower part, while volcanic and volcaniclastic rocks are predominate in the upper part (XBGMR, 1993 and Che et al., 1996). In this section, basalt, andesite, tuffaceous andesite, dacite, rhyolite, volcanic breccia and greywacke are widespread with intercalation of tuffaceous-sandy rhythmites. Fragments of feldspar and quartz phenocrysts, clasts of andesite, pyroclastic rock and clastic rock may be observed both in hand-samples and in thin sections (Fig. 4). 

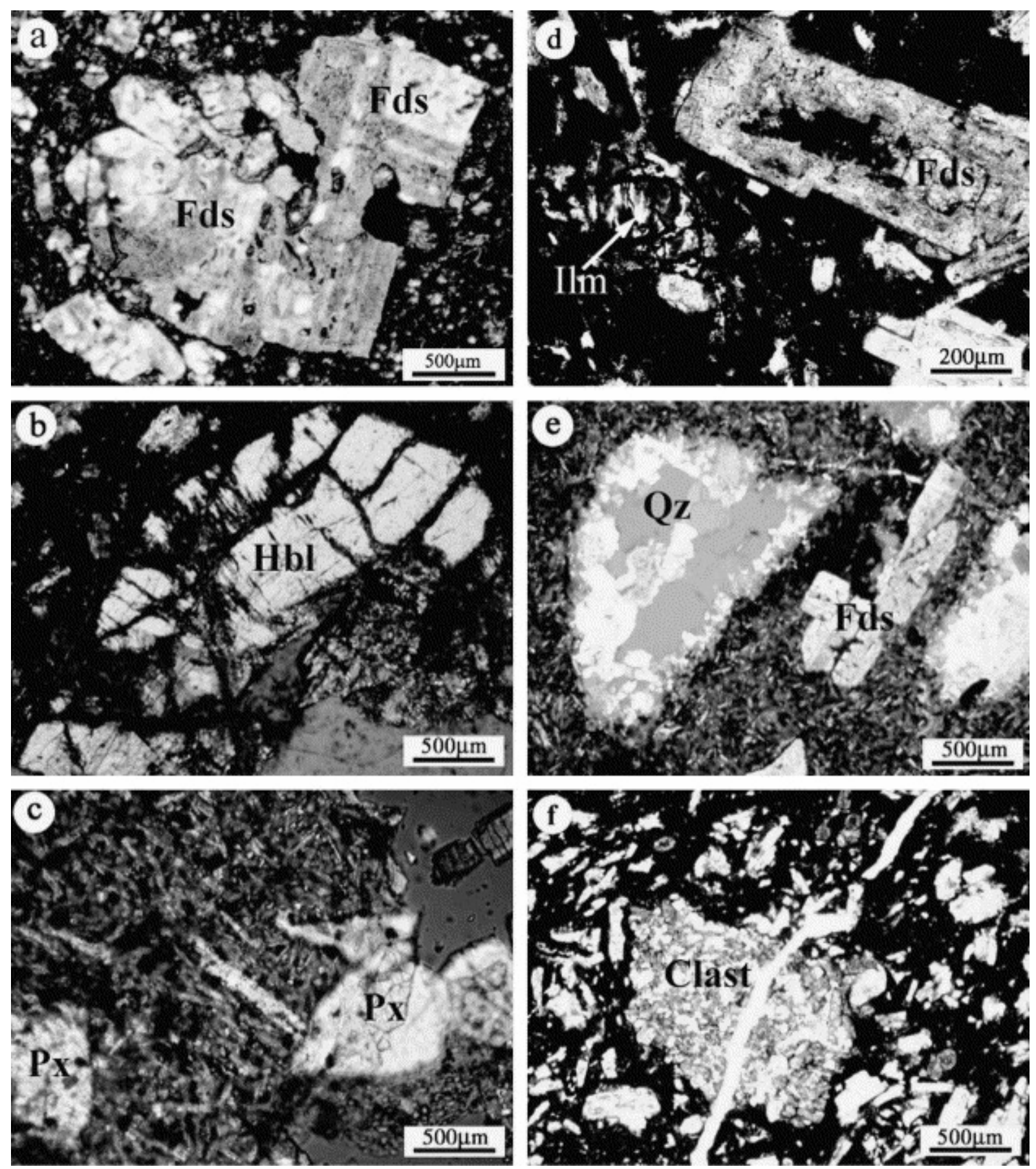

Fig. 4. Photomicrographs of volcanic rocks of the Yili Block. (a) Sample XJ174-6 showing volcanic microtexture and feldspar phenocrysts with multiple twins, (b) hornblende phenocrysts in sample XJ388, (c) sample XJ328 showing pyroxene phenocrysts and plagioclase needles in the matrix, (d) strongly altered feldspar and ilmenite mineralization in sample XJ325, (e) sample XJ365 showing feldspar and quartz-infilled vesicle, (f) andesite clast in sample XJ325. Abbreviation of minerals: Fds: feldspar; Hbl: hornblende; Px: pyroxene; Ilm: ilmenite; Qtz: quartz.

\subsection{The Nalati-Gongnaisi-Yuxi section}

This section includes two segments from Nalati County to Gongnaisi along the G218 National highway, and from Nalati to Yuxi along the G217 national highway, respectively (Fig. 3c). Both segments are mainly composed of Carboniferous andesitic rocks, unconformably 
overlain by Early Permian conglomerate, sandstone and siltstone (XBGMR, 1993). Both the volcanic rocks and the sedimentary strata are intruded by undated basic-intermediate dykes (XBGMR, 1992). The Nalati-Yuxi segment is composed of a large volume of porphyritic andesite referred to as the Yamansu Formation (C1y) (Fig. 2) and characterized by $2-5 \mathrm{~cm}$ andesine phenocrysts. The Yamansu Formation is overlain by the $\mathrm{C} 2$ terrigenous deposits yielding plant fossils (XBGMR, 1993) that suggest an Early Carboniferous age. In the Gongnaisi area, the unconformable Late Carboniferous siltstone, sandstone and conglomerate also display prominent volcanic rocks matched by a more diverse series of volcanic rocks: porphyritic andesite and dacite, felsitic porphyry, albitophyre and intermediate-acidic tuff.

\section{Petrography and mineral composition of volcanic rocks}

In most of the volcanic rocks, the plagioclase phenocrysts are altered to calcite and/or albite. Phenocryst and glass matrix can be commonly identified (Figs. 4a-e). The volcanic rocks are dominated by euhedral to subhedral plagioclase occurring both as phenocrysts and as fine needles in the groundmass (Figs. 4c and e), some of which show multiple twins and compositional zonation (Figs. $4 \mathrm{a}$ and $\mathrm{d}-\mathrm{e}$ ). Hornblende is frequently observed as phenocrysts (Figs. 4b and c) and in the groundmass, some parts of the hornblende having been altered to epidote and chlorite. Vesicles in some samples were filled with calcite and microcrystalline quartz (Fig. 4e). Clasts of andesite are observed in some samples (Fig. 4f).

Four polished thin sections of andesite from the northern Nileke section and the NalatiGongnaisi-Yuxi section were analyzed for mineral composition. Analysis was made on a JEOL JXA-8800 M electron microprobe located at the State Key Laboratory of Mineral Deposits, Nanjing University. Analysis was at $20 \mathrm{kV}$ with a $2 \times 10^{-8} \AA$ electron beam width. Synthetic and natural minerals were used as standards. The analytical results (Table 2) show that most of the plagioclase grains are albite and some grains have been replaced by calcite. This is evidence of low temperature recrystallisation. Therefore the "mobile element" compositions are to be considered carefully for geodynamic interpretation.

Table 2. : Electron microprobe analyzed data of mineral compositions of andesite in the Yili Block

\begin{tabular}{|c|c|c|c|c|c|c|c|c|c|c|c|c|}
\hline \multirow{2}{*}{$\begin{array}{l}\text { Samples } \\
\text { Analyses }\end{array}$} & \multicolumn{3}{|l|}{ XJ325 } & \multicolumn{3}{|l|}{ XJ354 } & \multicolumn{3}{|l|}{ XJ388 } & \multicolumn{3}{|l|}{ XJ390 } \\
\hline & 1 & 2 & 3 & 4 & 5 & 6 & 7 & 8 & 9 & 10 & 11 & 12 \\
\hline Minerals & $A b(C)$ & $\mathbf{A b}(\mathrm{C})$ & $\operatorname{Si}(\mathbf{R})$ & $\mathbf{A b}(\mathrm{C})$ & $\mathbf{A b}(\mathrm{C})$ & $A b(C)$ & Hbl(C) & Cal(C) & Hbl(C) & Cal(R) & $\mathbf{A b}(\mathbf{C})$ & $A b(C)$ \\
\hline $\mathrm{Na}_{2} \mathrm{O}$ & 11.673 & 0.076 & 0.007 & 10.112 & 11.669 & 10.235 & 0.407 & 0.078 & 0.314 & 0.036 & 10.349 & 9.368 \\
\hline $\mathrm{K}_{2} \mathrm{O}$ & 0.115 & 0.016 & 0.025 & 0.237 & 0.069 & 0.273 & 0.023 & 0.004 & - & 0.018 & 0.58 & 0.688 \\
\hline $\mathrm{MnO}$ & 0.004 & 0.301 & - & 0.015 & - & 0.007 & 0.093 & 2.18 & 0.148 & 1.447 & 0.089 & - \\
\hline $\mathrm{MgO}$ & 0.906 & 1.757 & 0.146 & 1.528 & 0.004 & 0.058 & 13.388 & 0.393 & 14.693 & 0.412 & 0.064 & 0.081 \\
\hline $\mathrm{TiO}_{2}$ & 0.038 & 0.139 & 0.08 & 0.037 & 0.005 & - & 0.777 & 0.008 & 0.477 & - & 0.093 & 0.016 \\
\hline $\mathrm{FeO}$ & 0.457 & 0.799 & 3.65 & 0.628 & 0.059 & 0.309 & 7.884 & 0.45 & 7.199 & 0.329 & 0.633 & 0.711 \\
\hline $\mathrm{Al}_{2} \mathrm{O}_{3}$ & 22.086 & 0.62 & 0.441 & 20.91 & 20.553 & 21.542 & 5.99 & 0.155 & 4.141 & 0.151 & 21.831 & 22.216 \\
\hline $\mathrm{CaO}$ & 0.443 & 52.54 & - & 3.477 & 2.195 & 0.342 & 22.007 & 56.584 & 21.744 & 56.743 & 0.586 & 0.617 \\
\hline $\mathrm{SiO}_{2}$ & 65.48 & 3.236 & 93.364 & 62.838 & 66.628 & 67.133 & 48.7 & 1.321 & 49.718 & 0.382 & 66.695 & 65.999 \\
\hline
\end{tabular}




\begin{tabular}{|c|c|c|c|c|c|c|c|c|c|c|c|c|}
\hline Samples & \multicolumn{3}{|l|}{ XJ325 } & \multicolumn{3}{|l|}{ XJ354 } & \multicolumn{3}{|l|}{ XJ388 } & \multicolumn{3}{|l|}{ XJ390 } \\
\hline Analyses & 1 & 2 & 3 & 4 & 5 & 6 & 7 & 8 & 9 & 10 & 11 & 12 \\
\hline Minerals & $A b(C)$ & $\mathbf{A b}(\mathrm{C})$ & $\mathrm{Si}(\mathrm{R})$ & $A b(C)$ & $A b(C)$ & $\mathbf{A b}(\mathrm{C})$ & $\mathrm{Hbl}(\mathrm{C})$ & $\operatorname{Cal}(\mathrm{C})$ & $\mathrm{Hbl}(\mathrm{C})$ & Cal(R) & $A b(C)$ & $A b(C)$ \\
\hline Total & 101.2 & 59.484 & 97.713 & 99.782 & 101.18 & 99.899 & 99.269 & 61.173 & 98.434 & 59.518 & 100.92 & 99.696 \\
\hline
\end{tabular}

Abbreviations: $\mathrm{Ab}=$ albite. $\mathrm{Si}=$ silica $. \mathrm{Cal}=$ calcite. $\mathrm{Hbl}=$ hornblende. $\mathrm{C}=$ center $. \mathrm{R}=$ rim.

\section{Geochemistry and geological implications}

\subsection{Analytical methods}

Nineteen representative samples of the three sections were analyzed for geochemical study. Major elements were determined by X-ray fluorescence (XRF) following the procedure described by Janney and Castillo (1997). Trace elements, including rare earth elements (REE), were determined by a PE-Elan 6000 ICP-MS. Both analyses were performed at the Guangzhou Institute of Geochemistry, Chinese Academy of Sciences. The analytical technique for ICP-MS analysis is similar to that described by Li (1997). Analytical errors are $1-3 \%$ for major elements and generally less than $0.7-10 \%$ for most trace elements. Major and trace elements data are shown in Table 1.

\subsection{Results}

Some samples exhibit relative high loss of ignition (LOI), especially samples XJ325, XJ326 and XJ358 that have LOI $>7 \%$ (Table 1). The compositions of mobile elements are likely to have changed and geochemical discriminations based on these elements cannot be used. Therefore in the following section, we only use geochemical diagrams based upon "immobile" elements such as REE, Zr, Ti, Yb, etc.

On the $\mathrm{Nb} / \mathrm{Y}$ versus $\mathrm{Zr}$ /Ti diagram (Fig. 5; Winchester and Floyd, 1976), volcanic rocks from each section are divided into three sub-groups: andesite (including one basaltic andesite), rhyodacite and trachyandesite. This diagram shows a linear differentiation trend within the calc-alkaline series field. Three samples (XJ335, XJ335-1 and XJ336) from the Axi section plot in the trachyandesite field due to their distinctive lower Ti contents that likely resulted from ilmenite fractionation. 


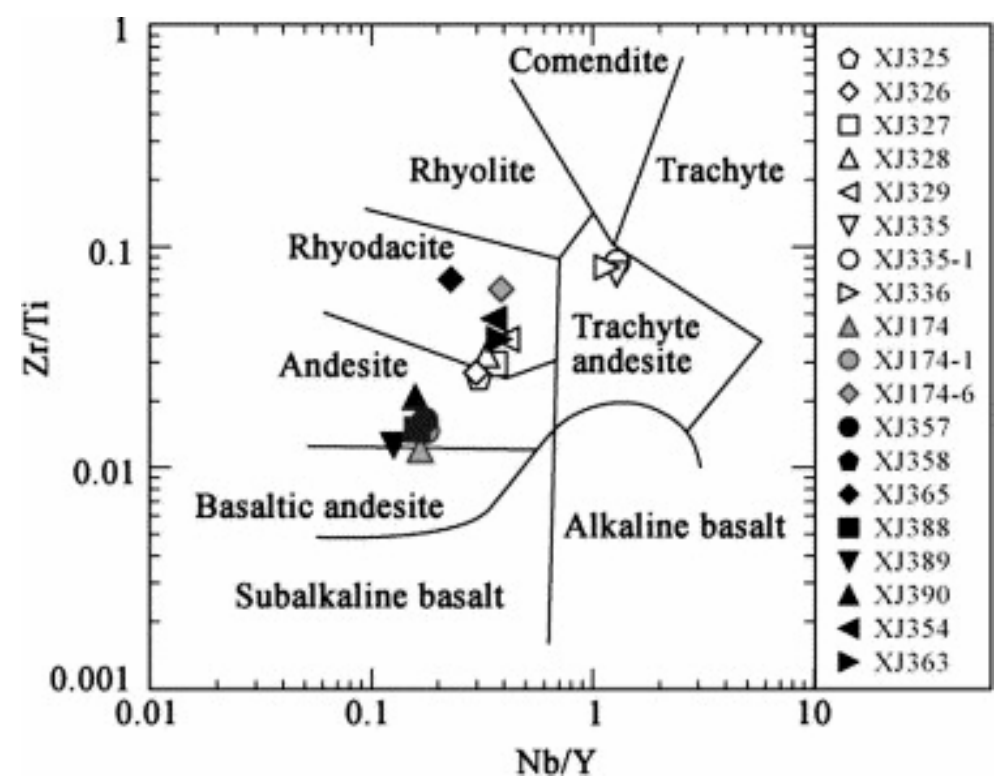

Fig. 5. Nb/Y versus $\mathrm{Zr} / \mathrm{Ti}$ diagram (Winchester and Floyd, 1976) plotting the volcanic rocks of the Yili Block. Open symbols: volcanic rocks of the Axi section; grey symbols: volcanic rocks of the northern Nileke section; black symbols: volcanic rocks of the Nalati-Gongnaisi-Yuxi section.

All the analyzed volcanic rocks have relatively high total REE concentrations ranging from 66 to $219 \mathrm{ppm}$ (Table 1). Negative Eu anomalies $(\delta \mathrm{Eu}=0.6113-0.9135)$ occur in most of volcanic rocks of the Axi and Nalati-Gongnaisi-Yuxi sections except sample XJ390. indicating crystal fractionation of plagioclase (Rollinson, 1993). Volcanic rocks of the northern Nileke section have no obvious Eu anomalies $(\delta \mathrm{Eu}=0.9975-1.0417)$ except XJ174$6(\delta \mathrm{Eu}=0.6838)$. The Chondrite-normalized REE distribution patterns (Fig. 6; using the normalizing values of Sun and McDonough, 1989) are characterized by a negative slope with $(\mathrm{La} / \mathrm{Yb})_{\mathrm{N}}>2.66$, indicating the fractionation of LREE relative to HREE. This feature is consistent with the calc-alkaline character of these rocks.
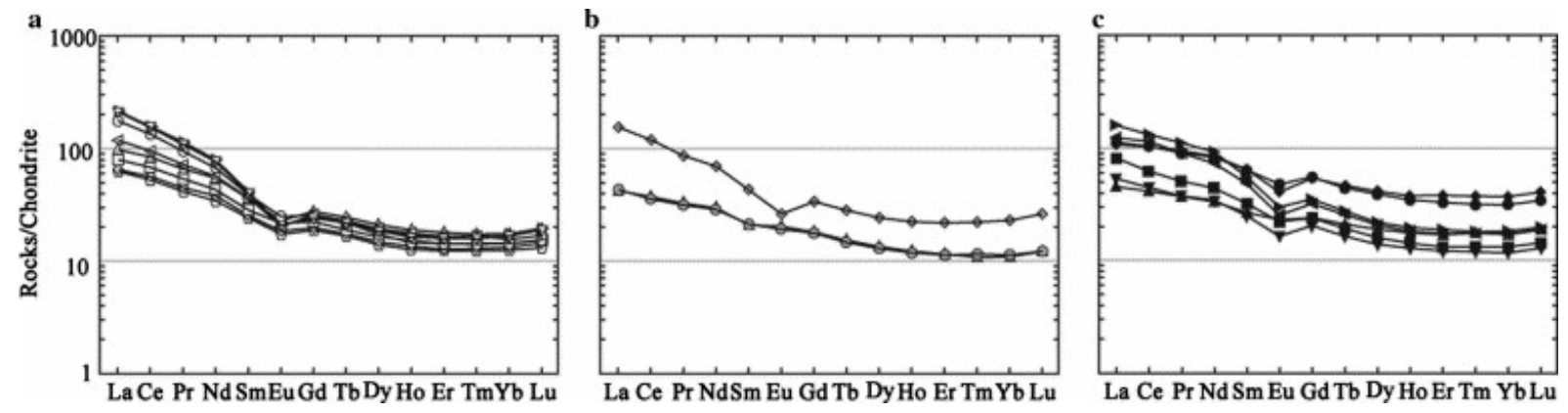

Fig. 6. Chondrite normalized REE patterns of volcanic rocks from the Yili Block. Normalizing values are from Sun and McDonough (1989). (a) Volcanic rocks of the Axi section; (b) volcanic rocks of the northern Nileke section; (c) volcanic rocks of the Nalati-Gongnaisi-Yuxi section. Symbols same as Fig. 5.

On the REE and trace element expanded spider diagrams (Fig. 7; Pearce, 1982 and Pearce, 1983), LILE such as $\mathrm{K}, \mathrm{Rb}$, Th and $\mathrm{Ba}$ are prominently enriched relative to MORB, while HFSE (Zr, Hf, Ta and Sm) have MORB-like concentrations. $\mathrm{Nb}$ and $\mathrm{Ta}$ display moderate negative anomalies relative to $\mathrm{Th}$ and $\mathrm{Ce}$. All samples have $\mathrm{Nb}$ contents of more than $3 \mathrm{ppm}$, similar to those of continental arc basalts $(3.3 \pm 1.6 \mathrm{ppm})$ and considerably higher than those of oceanic arc basalts (1.5 $\pm 1.0 \mathrm{ppm}$; McCulloch and Gamble, 1991). The $\mathrm{Nb}-\mathrm{Ta}$ depletion is a common feature of calc-alkaline magmas generated from sources that contain a $\mathrm{Nb}$ receptor 
(metasomatized mantle wedge) or from already $\mathrm{Nb}$-depleted sources (most crustal sources) (Hawkesworth et al., 1995, Rollinson, 1993 and Pearce and Peate, 1995).
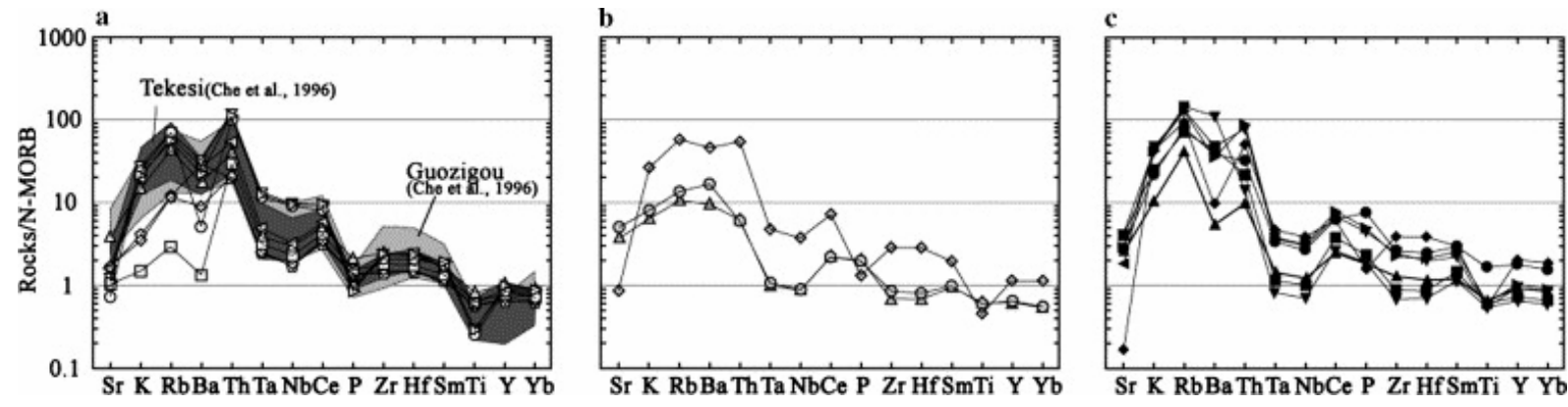

Fig. 7. N-MORB normalized spider diagrams of the volcanic rocks from the (a) Axi section, (b) northern Nileke section and (c) Nalati-Gongnaisi-Yuxi section, showing subduction related enrichment of LIL elements relative to HFS elements. Normalizing values are from Pearce (1983). Data of volcanic rocks from Tekesi and Guozigou are after Che et al. (1996). Symbols same as Fig. 5.

\subsection{Tectonic setting of the volcanic rocks}

The N-MORB normalized spider diagram (Pearce, 1982 and Pearce, 1983) shows a pronounced enrichment of LILE and a characteristic depletion of $\mathrm{Ta}$ and $\mathrm{Nb}$ (Fig. 7). Replotting already published data (Che et al., 1996) indicates that the volcanic rocks of Guozigou, immediately to the west of Yining, and those of Tekesi, south of Yining (Fig. 1), display similar geochemical features (Fig. 7a) that are typical of: (1) subduction-related magmas; (2) magmas generated by the partial melting of lower continental crust; or (3) mantle-derived magmas significantly contaminated by continental crust. $\mathrm{Sr}, \mathrm{Nd}$ and $\mathrm{Pb}$ isotopic studies are needed in order to provide compelling evidence concerning the origin of these volcanic rocks. However, "immobile element" ratios may eliminate some unlikely possibilities. In the case of magmas generated in a rifting environment as proposed by Perry et al., 1987 and Davis, 1991, partial melting of the lower crust is generally triggered by high heat flow related to uplift of the asthenosphere. In addition, the early stages of uplift generate intraplate magmas (continental tholeiites or alkaline basalts). This is obviously not the case of the Yili Carboniferous volcanic rocks that display calc-alkaline features only. Moreover, in rift environments, the hybridation of asthenosphere (OIB-like) and lithosphere (MORB-like) sources generally occurs and results in variable $\mathrm{Ta} / \mathrm{Hf}$ ratios on the $\mathrm{Hf}-\mathrm{Th}-\mathrm{Ta}$ diagram (Wood et al., 1979). On the Hf/3-Th-Ta triangular diagram (Fig. 8), all our samples (Fig. 8a), as well as those of Che et al. (1996) (Fig. 8b), plot along linear trends between typical calc-alkaline and IAT end-members without evidence for any occurrence of an intraplate (high $\mathrm{Ta} / \mathrm{Th}$ ) component. Therefore, the rifting hypothesis relative to partial melting of lower continental crust and contamination by the crust is considered unlikely. 


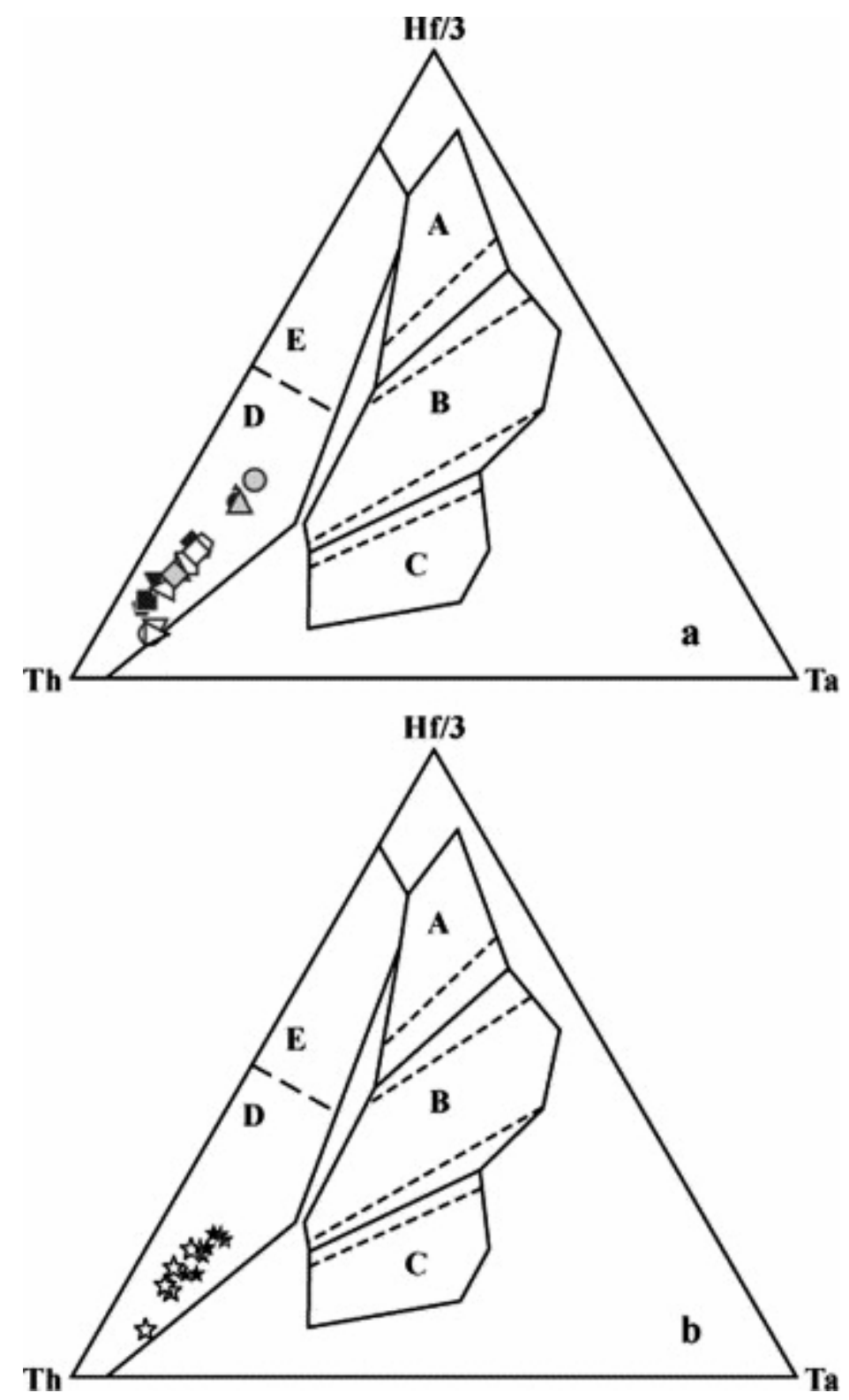

Fig. 8. Th-Hf/3-Ta discrimination diagrams (after Wood et al., 1979) of volcanic rocks from the Yili Block showing subduction-related calc-alkaline compositions. (a) This study, symbols same as Fig. 5; (b) Black stars: volcanic rocks of Guozigou; open stars: volcanic rocks of Tekesi, all data are from Che et al., 1996. Fields: A, NMORB; B, E-MORB and within-plate tholeiites; C, alkaline within-plate basalts; D, calc-alkaline basalts; E, Island-arc tholeiites.

The $\mathrm{Th} / \mathrm{Yb}$ vs Nb/Yb diagram (Fig. 9) distinguishes continental arc from oceanic-arc magmas (Pearce and Peate, 1995). All the samples plot within the continental-arc field and in the overlapping field of oceanic and continental arcs. The volcanic rocks in each section display a single linear trend depending upon slightly variable but high $\mathrm{Th} / \mathrm{Yb}$ ratios, due to higher $\mathrm{Th}$ and/or lower $\mathrm{Yb}$ contents (Table 1). Since $\mathrm{Yb}$ is essentially "immobile", these high $\mathrm{Th} / \mathrm{Yb}$ ratios presumably reflect the influence of subduction-derived fluids, resulting in $\mathrm{Th}$ enrichment. Although further isotopic evidence is needed to strengthen this interpretation, it may be concluded that Carboniferous calc-alkaline volcanic rocks of the Northern Yili Block are likely to have erupted in a continental active margin setting. 


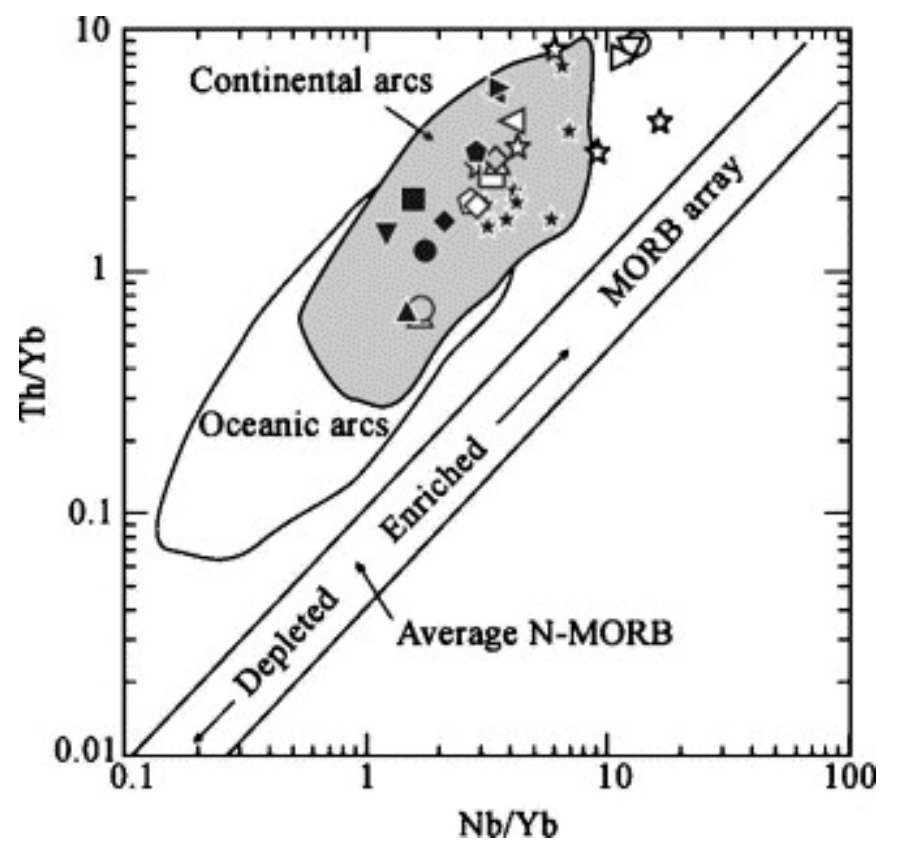

Fig. 9. $\mathrm{Th} / \mathrm{Yb}$ versus $\mathrm{Nb} / \mathrm{Yb}$ diagram after Pearce and Peate (1995) showing the subduction related continental arc affinities of the Carboniferous volcanic rocks of the Yili Block. Symbols same as in Fig. 5 and Fig. 8.

\section{Ophiolitic mélange of the Northern Tianshan Belt}

Ophiolitic mélanges are widely accepted as indicators of paleo-subduction and generally occur in association with island-arc volcanic rocks (Coleman, 1984, Coleman, 1989, Zhang and Zhou, 2001 and Zhang et al., 1984). In the study area, ophiolitic mélange was found in the Bayingou (Gao et al., 1998, Li, 1993 and Xiao et al., 1992)-Motuoshalagou-Gurt (Li and $\mathrm{Du}, 1994)$ zone located north of the Yili Block (Fig. 1). The mélange is composed of oceanic crust rocks, serpentinized peridotite, and flysch. The published geochemical results on the Bayingou and Gurt mafic rocks allow three magma types to be distinguished: N-MORB, OIB and IAT (Li and Du, 1994, Xiao et al., 1992 and Zhang and Zhou, 2001), suggesting genesis within an oceanic basin. The petrological and geochemical similarities of Bayingou, Motuoshalagou and Gurt ophiolitic rocks, along with the occurrence of Late Devonian to Early Carboniferous radiolarian and conodont fossils in cherts of the Bayingou mélange (Xiao et al., 1992) and C1-2 radiolarians in cherts of the Gurt mélange (Li and Du, 1994), allow us to infer that they were probably derived within a single Late Devonian to Early Carboniferous oceanic basin. Closure of this basin during subduction generated the active continental margin calc-alkaline magmatism in the Yili Block.

Although detailed petrological and structural studies of this unit are beyond the scope of this paper, the ophiolitic mélange and the North Tianshan turbidite can be interpreted as a subduction-accretion complex, and the northward thrusting observed in these units corresponds to south-dipping subduction of the oceanic basin. On the basis of age constraints provided by the active margin magmatic activity, this basin probably closed due to southward subduction during Tournaisian and Visean times. Since the mélange includes the $\mathrm{C} 1$ to $\mathrm{C} 2$ turbidite blocks (Fig. 2), it probably formed in the Late Carboniferous due to collision between the Yili Block and the North Tianshan and the Junggar Plate (Gao et al., 1998). 


\section{Discussion}

In all studied sections, the calc-alkaline volcanic rocks are closely associated with either carbonate sedimentary rocks or shallow water clastic deposits. In general, the Carboniferous sequence of the Yili Block displays a regressive character with a progressive evolution from a gently subsiding platform during the Early Carboniferous (C1) towards a Late Carboniferous sedimentation environment. No evidence for deepening or accelerating subsidence is found. Therefore, the calc-alkaline volcanic rocks erupted at the $\mathrm{C} 1-\mathrm{C} 2$ boundary cannot be related to a rifting event as proposed earlier by Che et al., 1996, Xia et al., 2002 and Xia et al., 2003 on the basis of "Within-plate basalt" discrimination diagram (i.e., $\mathrm{Zr}-\mathrm{Zr} / \mathrm{Y}$ ). In contrast, an active margin setting is consistent with: (1) the overall geochemical features of the erupted rocks, (2) evolution from a platform to a shallow water or terrestrial environment due to a $\mathrm{C} 1-$ C2 tectonic event, (3) accumulation of turbidite to the north of the Yili Block, and (4) the formation of a Late Carboniferous ophiolitic mélange. This tectonic setting is also consistent with that of the Bogda Arc in northern Eastern Tianshan, which is considered to be a Carboniferous continental volcanic arc formed by subduction of the Junggar Paleo-ocean (Charvet et al., 2001) or Turkestan Ocean (Heubeck, 2001 and Sengör and Natal'in, 1996).

Carboniferous volcanic arc rocks are widespread in the Yili Block. From north to south, they crop out nearly $200 \mathrm{~km}$ wide, which is uncommon for a volcanic arc. Such a width might not be a primary feature of this arc but probably was the result of later multiphase transcurrent displacements. On the basis of paleomagnetic data in the West Tianshan Belt in Kyrgyz (Bazhenov et al., 1999), earlier sinistral shearing along the southern boundary (CTNF) and later dextral shearing along the northern boundary (NTF) have been distinguished. The earlier event is proposed to have taken place during the "Early-Late Permian", but is still poorly constrained by structural and geochronological data. The later one, which is considered to have occurred during Late Permian to Early Jurassic times, is corroborated by kinematic and radiochronological studies. The Ar-Ar dating on biotite and muscovite from ductilely sheared slates or mylonites in the East Tianshan Belt constrains the age of this dextral wrenching at 280-250 Ma (Laurent-Charvet et al., 2002, Laurent-Charvet et al., 2003 and Shu et al., 1999). Further evidence of Permian transcurrent faulting within the interior of the Yili Block, such as the "Nilak fault" (Zhao et al., 2003; NLKF in Fig. 1), needs to be documented.

It is worth noting that Early Permian deposits unconformably overlie the Carboniferous strata. In most places, terrestrial Permian sediments are associated with intra-plate volcanic rocks, such as alkaline basalt or continental tholeiites and associated felsic rocks (Allen et al., 1995 and XBGMR, 1993). Moreover in the Baiyanggou area (Fig. 1), Permian alkaline pillow basalts are associated with chert and turbidite deposited in a narrow and deep basin that likely formed in a transtensional setting (Shu et al., 2005). Therefore we suggest that southward subduction closed the northern Tianshan oceanic basin and generated the active continental margin magmatism and ophiolitic mélange. This event was followed by Permian to Mesozoic regional intra-continental extension and transtensional faulting that was responsible for opening of the pull-apart basin, such as Turfan Basin (Fig. 1; Allen et al., 1995 and Natal'in and Sengör, 2005) associated with intraplate magmatism and the formation of the present shape of the Yili magmatic arc. 


\section{Conclusions}

Carboniferous volcanic rocks in the Yili Block erupted along a continental active margin as evidenced by (1) their calc-alkaline geochemistry, (2) prominent $\mathrm{Nb}$-Ta negative anomalies, (3) high $\mathrm{Th} / \mathrm{Ta}$ and $\mathrm{Hf} / \mathrm{Ta}$ ratios, and (4) marginal sedimentary series intercalated with volcanic rocks. The occurrence of a Late Carboniferous ophiolitic mélange and turbiditic rocks exhibiting a north-directed thrusting is attributed to a southward subduction of the North Tianshan oceanic basin, which was responsible for Yili calc-alkaline magmatism. This subduction was followed by Permian-Mesozoic intra-continental extension and transtensional faulting.

\section{Acknowledgements}

We would like to give our special appreciation to Prof. Ma Y.J., Wang J.L., Xu X., Wang B.L., Wang Y., Zhu B.Y., Guo H. (Bureau of National project 305, Xinjiang Uygur autonomous Region, China) and Li Y.A. (Xinjiang Bureau of Geology and Mineralogy Institute) for giving us their great help and support for field work. The constructive reviews by Dr. Natal'in and another anonymous reviewer significantly improved the earlier version of this study, Dr. J. Lytwyn, the editorial assistant and Dr. Romain Augier improved the English. This research was supported by the State Key Project for Basic Research of China (No. 2001CB409804).

\section{References}

Allen et al., 1995 M.B. Allen, A.M.C. Sengör and B.A. Natal'in, Junggar and Alakol basins as Late Permian to? Early Triassic extensional structures in a sinistral shearing zone in the Altaid orogenic collage, Central Asia, Journal of the Geological Society of London 152 (1995), pp. 327-338.

Allen et al., 1999 M.B. Allen, S.J. Vincent and P.J. Wheeler, Late Cenozoic tectonics of the Kepingtage thrust zone: interactions of the Tien Shan and Tarim basin, northwest China, Tectonics 1 (1999) (4), pp. 639-654.

Allen et al., 1993 M.B. Allen, B.F. Windley and C. Zhang, Paleozoic collisional tectonics and magmatism of the Chinese Tien Shan, Central Asia, Tectonophysics 220 (1993), pp. 89-115.

Avouac et al., 1993 J.P. Avouac, P. Tapponnier, M. Bai, H. You and G. Wang, Active thrusting and folding along the northern Tien Shan and Late Cenozoic rotation of the Tarim relative to Dzungaria and Kazakhstan, Journal of Geophysical Research 9 (1993) (B4), pp. 6755-6804.

Bazhenov et al., 1999 M.L. Bazhenov, V.S. Burtman and A.V. Dvorova, Permian paleomagnetism of the Tien Shan fold belt, Central Asia: post-collisional rotations and deformation, Tectonophysics 31 (1999) (2-4), pp. 303-329.

Burchfiel et al., 1999 B.C. Burchfiel, E.T. Brown, Q.D. Deng, X.Y. Feng, J. Li, P. Molnar, J.B. Shi, Z.M. Wu and H.C. You, Crustal shortening on the Margins of the Tien Shan, Xinjiang, China, International Geology Review 41 (1999), pp. 665-700. 
Charvet et al., 2001 J. Charvet, S. Laurent-Charvet, L.S. Shu and R.S. Ma, Paleozoic continental accretions in Central Asia around Junngar Block: new structural and geochronological data, Gondwana Research 4 (2001) (4), pp. 590-592. http://hal.archivesouvertes.fr/view by stamp.php?label=ISTO\&langue $=$ fr\&action todo=view\&id $=$ hal$\underline{00089717 \& \text { version }=1}$

Che et al., 1996 Z.C. Che, L. Liu, H.F. Liu and J.H. Luo, Review on the ancient Yili rift, Xinjiang, China, Acta Petrologica Sinica 1 (1996) (3), pp. 478-490 in Chinese with English abstract.

Chen et al., 2001 D.L. Chen, L. Liu, Z.C. Che and J.H. Luo, Geochemical characteristics and tectonic implication of Carboniferous volcanites in the Luotuogou area of Middle Tianshan, Acta Petrologica Sinica 1 (2001) (3), pp. 378-384 in Chinese with English abstract.

Chen et al., 1999 C.M. Chen, H.F. Lu, D. Jia, D.S. Cai and S.M. Wu, Closing history of the southern Tianshan oceanic basin, western China: an oblique collisional orogeny, Tectonophysics 302 (1999), pp. 23-40.

Chen et al., 2000a Y.B. Chen, A.Q. Hu, G.X. Zhang and Q.F. Zhang, Zircon U-Pb age of granitic gneiss on Duku highway in western Tianshan of China and its geological implications, Chinese Science Bulletin 4 (2000) (7), pp. 649-653.

Chen et al., 2000b Y.B. Chen, A.Q. Hu, G.X. Zhang and Q.F. Zhang, Precambrian basement age and characteristics of Southwestern Tianshan: Zircon U-Pb geochronology and $\mathrm{Nd}-\mathrm{Sr}$ istopic composition, Acta Petrologica Sinica 1 (2000) (1), pp. 91-98 in Chinese with English abstract.

Coleman, 1984 R.G. Coleman, The diversity of ophiolites, Geology Mijnbouw 63 (1984), pp. $141-150$.

Coleman, 1989 R.G. Coleman, Continental growth of Northwest China, Tectonics 8 (1989), pp. 621-635.

Cunningham et al., 1996 W.D. Cunningham, B.F. Windley, D. Dorjnamjaa, J. Badamgarov and M. Saandar, A structural transect across the Mongolian Western Altai: active transpressionnal mountain building in central Asia, Tectonics 1 (1996) (1), pp. 142-156.

Davis, 1991 P.M. Davis, Continental rift structures and dynamics with reference to teleseismic studies of the Rio Grande and East African rifts, Tectonophysics 19 (1991) (2-4), pp. 309-325.

Gao et al., 1997 J. Gao, G.Q. He and M.S. Li, Paleozoic orogenic processes of Western Tianshan Orogen, Earth Science-Journal of China University of Geosciences 22 (1997) (1), pp. 28-32 in Chinese with English abstract.

Gao et al., 1995 J. Gao, G.Q. He, M.S. Li, X.C. Xiao, Y.Q. Tang, J. Wang and M. Zhao, The mineralogy, petrology, metamorphic PTDt trajectory and exhumation mechanism of blueschist, south Tianshan, northwestern China, Tectonophysics 250 (1995), pp. 151-168. 
Gao et al., 1998 J. Gao, M.S. Li, X.C. Xiao, Y.Q. Tang and G.Q. He, Paleozoic tectonic evolution of the Tianshan Orogen, northern China, Tectonophysics 287 (1998), pp. 213-231.

Hawkesworth et al., 1995 C. Hawkesworth, S. Turner, K. Gallagher, A. Hunter, T. Bradshaw and N. Rogers, Calc-alkaline magmatism, lithospheric thinning and extension in the Basin and Range, Journal of Geophysical Research 100 (1995) (B7), pp. 10271-10286.

Heubeck, 2001 C. Heubeck, Assembly of Central Asia during the middle and late Paleozoic. In: M.S. Hendrix and G.A. Davis, Editors, Paleozoic and Mesozoic Tectonic Evolution of Central Asia: From Continental Assembly to Intracontinental Deformation 194, MemoirGeological Society of America, Boulder, Colorado (2001), pp. 1-22.

ICS, 2004 ICS (International Commission on Stratigraphy), 2004. International Stratigraphic Chart.

Janney and Castillo, 1997 P.E. Janney and P.R. Castillo, Geochemistry of Mesozoic Pacific MORB: constraints on melt generation and the evolution of the pacific upper mantle, Journal of Geophysical Research 102 (1997), pp. 5207-5229.

Jiang et al., 1995 C.Y. Jiang, W.K. Wu, X.R. Zhang and S.S. Cui, The change from island arc to rift valley: evidence from volcanic rocks of Awulale area, Acta Petrologica et Mineralogica 1 (1995) (4), pp. 289-300 in Chinese with English abstract.

Laurent-Charvet et al., 2003 S. Laurent-Charvet, J. Charvet, P. Monie and L.S. Shu, Late Paleozoic strike-slip shear zones in eastern Central Asia (NW China): new structural and geochronological data, Tectonics 2 (2003) (2), pp. 1099-1101.

Laurent-Charvet et al., 2002 S. Laurent-Charvet, J. Charvet, L.S. Shu, R.S. Ma and H.F. Lu, Palaeozoic late collisional strike-slip deformations in Tianshan and Altay, eastern Xinjiang, NW China, Terra Nova 1 (2002) (4), pp. 249-256.

Li et al., 1998 H.Q. Li, C.F. Xie, H.L. Chang, H. Cai, J.P. Zhu and S. Zhou, Study on Metallogenetic Chronology of Nonferrous and Precious Metallic Ore Deposits in North Xinjiang, Geology Publishing house, China, Beijing (1998) pp. 100-127 (in Chinese with English abstract).

Li and Du, 1994 S.H. Li and Q. Du, The ophiolites in Motogou-Gurt of Wusu County, Xinjiang Geology 1 (1994) (3), pp. 265-271 in Chinese with English abstract.

Li, 1993 X.D. Li, Late Paleozoic evolution of oceanic basin and thrust structure in northern Tianshan, Xinjiang, Xinjiang Geology 1 (1993) (3), pp. 207-214 in Chinese with English abstract.

Li, 1997 X.H. Li, Geochemistry of the Longsheng ophiolite from the southern margin of Yangtze carton, SE China, Geochemistry 31 (1997), pp. 323-337.

Ma et al., 1993 R.S. Ma, C.Y. Wang and S.F. Ye, Tectonic Framework and Crustal Evolution of Eastern Tianshan Mountains, Publishing House of Nanjing University, Nanjing (1993) p. 225 (in Chinese with English abstract). 
McCulloch and Gamble, 1991 M.T. McCulloch and J.A. Gamble, Geochemical and geodynamical constraints on subduction zone magmatism, Earth and Planetary Science Letters 102 (1991), pp. 358-374.

Natal'in and Sengör, 1994 Natal'in, B.A., Sengör, A.M.C., 1994. The tectonic setting of the Tien Shan within the Altaid orogenic belt. In: Geological Society of America Abstracts with program, Annual meeting, Seattle, pp. A464.

Natal'in and Sengör, 2005 B.A. Natal'in and A.M.C. Sengör, Late Paleozoic to Triassic evolution of the Turan and Scythian platforms: the pre-history of the Paloe-Tethyan closure, Tectonophysics 40 (2005) (3-4), pp. 175-202.

Pearce, 1982 J.A. Pearce, Trace element characteristics of lavas from destructive plate boundaries. In: R.S. Thorpe, Editor, Andesites: Orogenic Andesites and Related Rocks, Wiley, Chichester, UK (1982), pp. 525-548.

Pearce, 1983 J.A. Pearce, Role of the sub-continental lithosphere in magma genesis at active continental margins. In: C.J. Hawkesworth and M.J. Norry, Editors, Continental Basalts and Mantle Xenoliths, Shiva Press, Nantwich, UK (1983), pp. 230-249.

Pearce and Peate, 1995 J.A. Pearce and D.W. Peate, Tectonic implications of the composition of volcanic arc magmas, Annual Review of Earth and Planetary Sciences 23 (1995), pp. 251285 .

Perry et al., 1987 F.V. Perry, W.S. Baldridge and D.S. DePaolo, Role of asthenosphere and lithosphere in the genesis of Late Cenozoic basaltic rocks from the Rio Grande Rift and adjacent regions of the southwestern United States, Journal of Geophysical Research 92 (1987), pp. 9193-9213.

Rollinson, 1993 H.R. Rollinson, Using Geochemical Data: Evaluation, Presentation, Interpretation, Longman scientific technical, New York (1993) pp. 48-213.

Sengör and Natal'in, 1996 A.M.C. Sengör and B.A. Natal'in, Paleotectonics of Asia: fragments of a synthesis. In: A. Yin and M. Harrison, Editors, The Tectonic Evolution of Asia. Rubey Colloquium, Cambridge University Press, Cambridge (1996), pp. 486-640.

Sengör et al., 1993 A.M.C. Sengör, B.A. Natal'in and V.S. Burtman, Evolution of the Altaid tectonic collage and Paleozoic crust growth in Eurasia, Nature 364 (1993), pp. 299-307.

Shi et al., 1994 Y.S. Shi, H.F. Lu, D. Jia and D.G. Howell, Paleozoic plate tectonic evolution of the Tarim and western Tianshan Regions, Western China, International Geological Review 36 (1994), pp. 1058-1066.

Shu et al., 1999 L.S. Shu, J. Charvet, L.Z. Guo, H.F. Lu and S. Laurent-Charvet, A Large scale Paleozoic dextral strike-slip shear zone: the Aqikkudug-Weiya zone along the Northern margin of Central Tianshan belt, Xinjiang, NW China, Acta Geologica Sinica 7 (1999) (4), pp. $148-162$. 
Shu et al., 2002 L.S. Shu, J. Charvet, H.F. Lu and S. Laurent-Charvet, Paleozoic accretioncollision events and kinematics of ductile deformation in the central-southern Tianshan Belt, China, Acta Geologica Sinica 76 (2002) (3), pp. 308-323.

Shu et al., 2000 L.S. Shu, Y.T. Chen, H.F. Lu, J. Charvet, S. Laurent-Charvet and D.H. Yin, Paleozoic accretionary terranes in Northern Tianshan, NW China, Chinese Geochemistry 1 (2000) (3), pp. 193-202.

Shu et al., 2003 L.S. Shu, B. Wang, F. Yang, H.F. Lu, J. Charvet and S. Laurent-Charvet, Polyphase tectonic events and Mesozoic-Cenozoic basin-range coupling in the Chinese Tianshan belt, Acta Geologica Sinica 7 (2003) (4), pp. 457-467.

Shu et al., 2005 L.S. Shu, W.B. Zhu, B. Wang, M. Faure, J. Charvet and D. Cluzel, The postcollision intracontinental rifting and olistostrome on the southern slope of Bogda Mountains, Xinjiang, Acta Petrologica Sinica 2 (2005) (1), pp. 25-36 in Chinese with English abstract.

Sun and McDonough, 1989 Sun, S.S., McDonough, W.F., 1989. Chemical and isotopic systematics of ocean island basalts: implications for mantle composition and processes. In: Saunders, A.D., Norry, M.J. (Eds). Magmatism in the Ocean Basins. Geological Society, London, Special Publications, pp. 313-345.

Tapponnier and Molnar, 1979 P. Tapponnier and P. Molnar, Active faulting and Cenozoic tectonics of the Tienshan, Mongolia and Baykal regions, Journal of Geophysical Research 84 (1979), pp. 3425-3459.

Wang et al., 1997 B.Y. Wang, Q. Li and J.B. Liu, Geological structures of the Middle Tianshan Mountains along the Dushanzi-Kuqa highway, Xinjiang Geology 1 (1997) (2), pp. 135-154 in Chinese with English abstract.

Winchester and Floyd, 1976 J.A. Winchester and P.A. Floyd, Geochemical magma type discrimination: application to altered and metamorphosed basic igneous rocks, Earth and Planetary Science Letters 28 (1976), pp. 459-469. Abstract | Abstract + References | PDF $(770 \mathrm{~K})$

Windley et al., 1990 B.F. Windley, M.B. Allen, C. Zhang, Z.Y. Zhao and G.R. Wang, Paleozoic accretion and Cenozoic redeformation of the Chinese Tien Shan range, Central Asia, Geology 18 (1990), pp. 128-131.

Wood et al., 1979 D.A. Wood, J.L. Joron and M. Treuil, A re-appraisal of the use of trace elements to classify and discriminate between magma series erupted in different tectonic setting, Earth and Planetary Science Letters 45 (1979), pp. 326-336.

XBGMR, 1992 XBGMR (Xinjiang Bureau of Geology and Mineral Resources), 1992. Geological map of Xinjiang Uygur Autonomy Region, Geological Publishing House, Beijing, four sheets, scale 1:1,500.000.

XBGMR, 1993 XBGMR (Xinjiang Bureau of Geology and Mineral Resources), 1993. Regional geology of Xinjiang Uygur Autonomy Region. Geology Publishing House, Beijing, pp. 1-841 (in Chinese with English abstract). 
Xia et al., 2003 L.Q. Xia, X.Y. Xu, Z.C. Xia, X.M. Li, Z.P. Ma and L.S. Wang, Carboniferous post-collisional rift volcanism of the Tianshan Mountains, Northwestern China, Acta Geologica Sinica 7 (2003) (3), pp. 338-360.

Xia et al., 2002 L.Q. Xia, G.W. Zhang, Z.C. Xia, X.Y. Xu, Y.P. Dong and X.M. Li, Constraints on the timing of opening and closing of the Tianshan Paleozoic oceanic basin: evidence from Sinian and Carboniferous volcanic rocks, Geological Bulletin of China 2 (2002) (2), pp. 55-62 in Chinese with English abstract.

Xiao et al., 1992 X.C. Xiao, Y.Q. Tang, Y.M. Feng, B.Q. Zhu, J.Y. Li and M. Zhao, Tectonic Evolution of the Northern Xinjiang and its Adjacent Regions, Geology Publishing House, Beijing (1992) pp. 12-47 (in Chinese with English abstract).

Zhang and Zhou, 2001 Q. Zhang and G.Q. Zhou, Ophiolites in China, Science Press, Beijing (2001) pp. 1-182 (in Chinese with English abstract).

Zhang et al., 1984 Z.M. Zhang, J.G. Liu and R.G. Coleman, An outline of the plate tectonics of China, Bulletin of Geological Association of America 95 (1984), pp. 295-312.

Zhao et al., 2003 J.M. Zhao, G.D. Liu, Z.X. Lu, X.K. Zhang and G.Z. Zhao, Lithospheric structure and dynamic processes of the Tianshan orogenic belt and the Junggar basin, Tectonophysics 376 (2003), pp. 199-239.

Zhou et al., 2001 D. Zhou, S.A. Graham, E.Z. Chang, B.Y. Wang and B. Hacker, Paleozoic tectonic amalgamation of the Chinese Tianshan: Evidence from a transect along the Dushanzi-Kuqa highway. In: M.S. Hendrix and G.A. Davis, Editors, Paleozoic and Mesozoic Tectonic Evolution of Central Asia: From Continental Assembly to Intracontinental Deformation 194, Boulder, Colorado, Geological Society of America Memoir (2001), pp. 2346. 